Pesq. Vet. Bras. 37(3):291-294, março 2017 DOI: $10.1590 / \mathrm{S} 0100-736 \mathrm{X} 2017000300014$

\title{
Effect of racial crossing on the scrotum-testicular biometry in sheep submitted to scrotal insulation ${ }^{1}$
}

\author{
Antônio F.S. Lisboa-Neto ${ }^{2 *}$, Paulo G. Mariano-Filho ${ }^{3}$, Jean R. Carvalho ${ }^{3}$, Morgana S. \\ Araújo $^{4}$, Amilton C. Santos ${ }^{2}$, Felicianna C.F. Machado ${ }^{3}$, Manoel L. Silva-Filho ${ }^{3}$ \\ and Antônio A.N. Machado-Júnior ${ }^{3}$
}

\begin{abstract}
Lisboa-Neto A.F.S., Mariano-Filho P.G., Carvalho J.R., Araújo M.S., Santos A.C., Machado F.C.F., Silva-Filho M.L. \& Machado-Júnior A.A.N. 2017. Effect of racial crossing on the scrotum-testicular biometry in sheep submitted to scrotal insulation. Pesquisa Veterinária Brasileira 37(3):291-294. Faculdade de Medicina Veterinária e Zootecnia, Avenida Prof. Doutor Orlando Marques de Paiva 87, Butantã, São Paulo, SP 05508-010, Brazil. E-mail: lisboaneto@usp.br

The objective of this study was to evaluate the effect of the racial crossing on scrotumtesticular biometric characteristics of four sheep Santa Ines and four crossbred (Santa Ines $\mathrm{x}$ Dorper) submitted to scrotal insulation, following the return of these characteristics to values previously reported. For this, two measurements were made regarding the scrotal circumference (SC), length (L) and testicular width (W) before treatments. The testicular volume $(\mathrm{V})$ was calculated by the formula $\mathrm{V}=2\left[\left(\mathrm{r}^{2}\right) \times \pi \times \mathrm{H}\right]$. The pouches were made with double-layer plastic, internally lined with cotton, and fixed around the spermatic funiculus and scrotum with adhesive tape and bandage remaining in this position for seven days. Measurements were made every seven days, totaling 15 measurements throughout the experiment. The data were submitted to analysis of variance (ANOVA) to a randomized block design with two blocks, 15 treatments and four replications. The variables analyzed were subjected to Dunnett test at $5 \%$ probability, to compare the values obtained before and after insulation. For comparison between the breeds, the variables were submitted to Tukey test at $5 \%$ probability. All animals studied suffered significant influence $(\mathrm{P}<0.05)$ after scrotal insulation, but Santa Ines returned to the values previously observed in a shorter period than the crossbred. In summary, sheep Santa Ines have a higher resistance than crossbred animals when subjected to thermal stress induced by scrotal insulation.
\end{abstract}

INDEX TERMS: Racial crossing, scrotum-testicular biometry, sheep, scrotal insulation, circle, testis, thermoregulation.

RESUMO.- [Efeito do cruzamento racial sobre a biometria escroto-testicular em ovinos submetidos à insulação escrotal.] Objetivou-se neste trabalho avaliar o efeito do cruzamento sobre as características biométricas escroto-testiculares de carneiros da raça Santa Inês e mes-

\footnotetext{
${ }^{1}$ Received on June 22, 2016.

Accept for publication on August 19, 2016.

2 Programa de Pós-Graduação em Anatomia dos Animais Domésticos e Silvestres, Faculdade de Medicina Veterinária e Zootecnia, Av. Prof. Orlando Marques de Paiva 87, Butantã, São Paulo, SP 05508-010, Brazil.*Corresponding author: lisboaneto@usp.br

${ }^{3}$ Universidade Federal do Piauí, Campus Professora Cinobelina Elvas, BR-135 Km 3, Bairro Planalto Horizonte, Bom Jesus, PI 64900-000, Brazil.

${ }^{4}$ Programa de Pós-Graduação em Zootecnia, Universidade Federal do Piauí, Campus Professora Cinobelina Elvas, BR-135 Km 3, Bairro Planalto Horizonte, Bom Jesus, PI 64900-000.
}

tiços (Santa Inês x Dorper), submetidos à insulação escrotal, acompanhando o retorno dessas características aos valores previamente observados. Para isso, foram realizadas duas mensurações referentes à circunferência escrotal (CE), comprimento (C) e largura testicular (L), antes da insulação. $\mathrm{O}$ volume testicular (V) foi calculado pela fórmula $\mathrm{V}=2\left[\left(\mathrm{r}^{2}\right) \times \pi \times \mathrm{h}\right]$. As bolsas de insulação foram fixadas ao redor do funículo espermático e escroto com fita adesiva e esparadrapo, permanecendo por sete dias. Após o período de insulação, as mensurações foram realizadas a cada sete dias, totalizando 15 mensurações durante todo o experimento. Os dados obtidos foram submetidos à análise de variância (ANOVA) para um delineamento em blocos casualizados, com dois blocos, 15 tratamentos e quatro repetições. As variáveis analisadas foram submetidas ao teste 
de Dunnett a 5\% de probabilidade, para comparar os valores obtidos antes e após a insulação. Para a comparação entre as raças, as variáveis foram submetidas ao teste de Tukey a $5 \%$ de probabilidade. Todos os animais estudados sofreram influência significativa $(\mathrm{P}<0,05)$ após a insulação escrotal, porém os carneiros da raça Santa Inês retornaram aos valores anteriormente observados em um espaço de tempo mais curto do que os mestiços. Conclui-se que carneiros da raça Santa Inês apresentam maior resistência do que animais mestiços quando submetidos ao estresse térmico induzido pela insulação escrotal.

TERMOS DE INDEXAÇÃO: Cruzamento racial, biometria escroto-testicular, ovinos, insulação escrotal, carneiro, circunferência, termorregulação, testículo.

\section{INTRODUCTION}

Sheep farming is a traditional activity in the northeastern semi-arid region in Brazil and presents itself as an alternative to the socioeconomic growth and subsistence activity, providing economic growth for low-income families in that region (Santos \& Santos 2011).

The racial crossing is an important tool for genetic improvement in order to increasing productivity. An example is industrial crossbreeding, which is a practice that favors the combination of desirable characteristics of each breed and the exploitation of heterosis (Notter 2000, Oliveira et al. 2014), but its effectiveness depends on some factors, such as the breeds used, the individuality of the animals and the nutritional management provided to animals (Silva Sobrinho 2001).

An exotic breed of great importance and widely used in this type of crossing is the Dorper, considered precocious, with high weight gain, high quality of carcass, good conformation and fat distribution (Souza \& Leite 2000, Barros et al. 2005). The use of native breed such as Santa Ines improves production and performance, and this intersection can generate offspring with greater weight gain potential (Madruga et al. 2006).

The weather of the Northeast of Brazil is characterized by high temperatures throughout the year, which can directly influence the mechanisms of testicular thermoregulation and thus the reproductive functions of the male. Among the ovine breeds exploited in the Northeast, the Santa Ines has the highest expression due to the size, production of matrices for milk and because the reproducers are very used at intersections schemes with native animals and exotic breeds, besides the fact that this breed is well adapted to the region (Oliveira \& Lima 1994, Nunes et al. 1997).

Campos et al. (2003), Teodoro et al. (2013) describe that there is significant influence of ambient temperature on the biometry of the reproductive organs, and in the dry season the values decrease considerably. According to Assis et al. (2008), the testicular biometry is considered an important factor of evaluation in sheep due to its high correlation with sperm production and reproductive performance as well as production characteristics, such as body development transmitted to offspring.

Thus, the aim of this study was to evaluate the effect of racial crossing on scrotum-testicular biometry in Santa
Ines and crossbred sheep (Dorper x Santa Ines) submitted to scrotal insulation.

\section{MATERIALS AND METHODS}

Eight sheep were used (four Santa Ines and four crossbredSanta Ines x Dorper). All animals were healthy with age ranging from 18 to 24 months. A general clinical examination, with emphasis on the reproductive system in order to verify the integrity of these organs through palpation was performed.

The experiment was conducted in the experimental sheepfold of Piauí Federal University, Campus Professor Cinobelina Elvas at Bom Jesus, PI, Brazil, in March and July 2015. This town is located at $09^{\circ} 04^{\prime} 28^{\prime \prime}$ of South latitude, $44^{\circ} 21^{\prime} 31^{\prime \prime}$ of West longitude and $277 \mathrm{~m}$ of altitude.

The animals received elephant-grass based diet (Pennisetum purpureum) and were supplemented with commercial feed for sheep, mineral salt and water ad libitum, being confined during the experimental period.

For evaluation of the scrotum-testicular biometry, two measurements were made with seven days before placing the insulation pouches, in order to determine the normal measures of the evaluated organs. The pouches were made with double-layer plastic, internally lined with cotton, and fixed around the spermatic funiculus and scrotum with adhesive tape and bandage remaining in the testes of the animals for seven days.

The evaluated measures were: testicular length (L), measuring the testicles from capitata to caudata extremity, excluding the head and tail of the epididymis; testicular width (W) at the middle third of each testicle in the lateromedial portion, using a graduated caliper; and scrotal circumference (SC) using a measuring tape in the wider portion of the scrotum.

To calculate the testicular volume (V) cylinder formula $V=2$ $\left[\left(\mathrm{r}^{2}\right) \times \pi \times \mathrm{h}\right]$ with $\mathrm{r}=$ radius calculated from the width $(\mathrm{W} / 2), \mathrm{h}$ $=$ length or height, e $\pi=3.14$ was adopted. The volume was expressed in $\mathrm{cm}^{3}$ (Fields et al. 1979, Unanian et al. 2001).

The first scrotum-testicular biometry was made on the day that the pouches were taken (day 0 ) and thereafter, every seven days, totaling 15 measurements. The data were submitted to analysis of variance (ANOVA) for a randomized block design, with two blocks, 15 treatments and four replications. The analyzed variables were subjected to Dunnett test at $5 \%$ probability to compare the values obtained before treatment with those obtained in the following days. For comparison between the breeds, the variables were submitted to Tukey test at 5\% probability.

\section{RESULTS AND DISCUSSION}

The L, W, V e SC values for studied animals are present in Table 1. Before insulation, the average values of $L$ and $W$ of Santa Ines were $7.9 \pm 1.1 \mathrm{~cm}$ and $5.9 \pm 1.2 \mathrm{~cm}$, respectively. It was observed that after the removal of insulating pouches (Day 0), there was a significant decrease $(\mathrm{P}<0.05)$ in L measurements in both breeds studied, but these changes were significant in W only from 14 th day in Santa Ines and at the 7 th day in the crossbred. In Santa Ines, significant differences remained until day 84 for $\mathrm{L}$ and until day 42 for W, e.g. on day 91, L returned to baseline and at day $49, \mathrm{~W}$ returned to pre-insulation values $(\mathrm{P}>0.05)$.

The SC and V before insertion were $29.4 \pm 4.4 \mathrm{~cm}$ and $487.1 \pm 231.2 \mathrm{~cm}^{3}$ respectively (Table 1 ). Both showed significant differences $(\mathrm{P}<0.05)$ at day 14 in both groups. In Santa Ines the SC returned to normal on day 42 and V returned to pre-insulation value at day 56 . In the group of crossbred, 
Table 1. Scrotum-testicular biometry for sheep Santa Ines and crossbred (Santa Ines x Dorper) submitted to scrotal insulation in Bom Jesus/PI, Brazil

\begin{tabular}{|c|c|c|c|c|c|c|c|c|}
\hline \multirow[t]{3}{*}{ Parameters } & \multicolumn{8}{|c|}{ Breed } \\
\hline & \multicolumn{4}{|c|}{ Santa Ines } & \multicolumn{4}{|c|}{ Crossbred } \\
\hline & $\mathrm{L}^{1}$ & $\mathrm{~W}^{2}$ & $\mathrm{~V}^{3}$ & $\mathrm{SC}^{4}$ & $\mathrm{~L}^{1}$ & $\mathrm{~W}^{2}$ & $\mathrm{~V}^{3}$ & $\mathrm{SC}^{4}$ \\
\hline Before & $7.9 \pm 1.1$ & $5.9 \pm 1.2$ & $487.1 \pm 231.2$ & $29.4 \pm 4.4$ & $8.1 \pm 0.4$ & $6.0 \pm 0.6$ & $459.5 \pm 92.1$ & $31.3 \pm 0.9$ \\
\hline 0 & $5.8 \pm 0.9^{*}$ & $6.1 \pm 1.0$ & $369.3 \pm 159.6$ & $28.3 \pm 4.3$ & $6.5 \pm 0.3^{*}$ & $6.2 \pm 0.5$ & $395.8 \pm 59.3$ & $30.3 \pm 1.3$ \\
\hline 7 & $5.6 \pm 1.0^{*}$ & $4.9 \pm 1.2$ & $245.5 \pm 141.7^{*}$ & $25.5 \pm 3.5^{*}$ & $6.0 \pm 0.3^{*}$ & $4.6 \pm 0.2^{*}$ & $194.4 \pm 17.5^{*}$ & $26.3 \pm 0.9^{*}$ \\
\hline 14 & $5.8 \pm 0.6^{*}$ & $4.0 \pm 0.8^{*}$ & $160.6 \pm 72.8^{*}$ & $24.5 \pm 3.5^{*}$ & $6.0 \pm 0.4^{*}$ & $4.1 \pm 0.4^{*}$ & $161.7 \pm 36.7^{*}$ & $25.1 \pm 0.9 *$ \\
\hline 21 & $5.3 \pm 0.8^{*}$ & $4.1 \pm 0.8^{*}$ & $152.0 \pm 74.5^{*}$ & $23.5 \pm 3.0^{*}$ & $5.4 \pm 0.3^{*}$ & $4.0 \pm 0.4^{*}$ & $132.8 \pm 28.1 *$ & $24.3 \pm 0.6^{*}$ \\
\hline 28 & $5.3 \pm 0.9^{*}$ & $4.0 \pm 0.6^{*}$ & $148.5 \pm 59.3^{*}$ & $24.4 \pm 2.9^{*}$ & $6.0 \pm 0.5^{*}$ & $4.2 \pm 0.3^{*}$ & $168.6 \pm 29.6 *$ & $24.3 \pm 0.8^{*}$ \\
\hline 35 & $5.4 \pm 0.7^{*}$ & $4.2 \pm 0.7^{*}$ & $163.4 \pm 65.6^{*}$ & $25.4 \pm 2.4^{*}$ & $5.6 \pm 0.3^{*}$ & $4.3 \pm 0.3^{*}$ & $163.8 \pm 29.3^{*}$ & $25.4 \pm 1.1^{*}$ \\
\hline 42 & $5.6 \pm 0.8^{*}$ & $4.5 \pm 0.7^{*}$ & $196.9 \pm 79.7^{*}$ & $26.6 \pm 3.6$ & $5.5 \pm 0.5^{*}$ & $4.7 \pm 0.4^{*}$ & $193.3 \pm 49.8^{*}$ & $26.3 \pm 1.8^{*}$ \\
\hline 49 & $5.8 \pm 1.1^{*}$ & $4.9 \pm 1.1$ & $248.3 \pm 133.3^{*}$ & $26.5 \pm 4.0$ & $6.3 \pm 0.6^{*}$ & $4.5 \pm 0.5^{*}$ & $211.7 \pm 71.9 *$ & $26.8 \pm 1.8^{*}$ \\
\hline 56 & $5.6 \pm 0.7 *$ & $5.9 \pm 0.9$ & $325.2 \pm 126.0$ & $28.3 \pm 4.3$ & $5.8 \pm 0.2 *$ & $5.5 \pm 0.3$ & $278.5 \pm 38.9 *$ & $27.5 \pm 1.8 *$ \\
\hline 63 & $5.8 \pm 1.0^{*}$ & $5.7 \pm 1.0$ & $335.9 \pm 147.1$ & $27.8 \pm 3.8$ & $5.7 \pm 0.3^{*}$ & $5.6 \pm 0.4$ & $281.4 \pm 54.0 *$ & $28.1 \pm 1.9^{*}$ \\
\hline 70 & $5.9 \pm 1.0^{*}$ & $5.6 \pm 0.9$ & $328.5 \pm 143.7$ & $27.6 \pm 3.9$ & $6.3 \pm 0.5^{*}$ & $4.9 \pm 0.4^{*}$ & $240.5 \pm 63.9 *$ & $27.5 \pm 1.8 *$ \\
\hline 77 & $6.5 \pm 1.1^{*}$ & $5.6 \pm 1.2$ & $368.0 \pm 162.0$ & $27.0 \pm 4.0$ & $6.0 \pm 0.7^{*}$ & $5.4 \pm 0.6$ & $285.1 \pm 99.1 *$ & $28.0 \pm 2.0 *$ \\
\hline 84 & $6.1 \pm 1.1^{*}$ & $5.6 \pm 1.0$ & $335.8 \pm 157.0$ & $27.9 \pm 3.7$ & $6.3 \pm 0.6^{*}$ & $5.5 \pm 0.4$ & $299.6 \pm 79.2 *$ & $28.0 \pm 2.0 *$ \\
\hline 91 & $7.0 \pm 0.9$ & $5.3 \pm 1.0$ & $342.1 \pm 152.3$ & $27.3 \pm 3.8$ & $6.8 \pm 0.5^{*}$ & $5.2 \pm 0.5^{*}$ & $295.0 \pm 65.7^{*}$ & $28.0 \pm 2.0 *$ \\
\hline Total & $6.0 \pm 0.5$ & $5.1 \pm 0.7$ & $280.5 \pm 86.4$ & $26.7 \pm 1.4$ & $6.1 \pm 0.4$ & $5.0 \pm 0.6$ & $250.7 \pm 71.8$ & $27.1 \pm 1.5$ \\
\hline
\end{tabular}

$\bar{*}$ Statistical differences $(\mathrm{P}<0.05):{ }^{1}$ testicular length, ${ }^{2}$ testicular width, ${ }^{3}$ testicular volume, ${ }^{4}$ scrotal circumference.

after $91^{\text {st }}$ day none of these parameters had returned to pre-insulation values.

Souza et al. (2007) conducted a study with 76 sheep Santa Ines bred in Campo Maior, Piauí, Brazil, during the dry season and low food availability. The animals studied had age of $27.85 \pm 3.85$ months and average weight of $46.75 \pm 7.51 \mathrm{~kg}$. The average values of the scrotum-testicular biometry were: $31.91 \pm 2.33 \mathrm{~cm}$ of circumference; $8.85 \pm 0.85 \mathrm{~cm}$ length; and $6.06 \pm 0.61 \mathrm{~cm}$ width. In the present study the observed measurements were lower in both Santa Ines and crossbred.

This fact may be explained due to the fact that age and weight of the animals were lower than those studied by the authors, and because the scrotum-testicular biometry has a positive correlation with age and body weight of the animals (Silva et al. 2000, Dias et al. 2003, Boligon et al. 2007, Yokoo et al. 2007, Santos et al. 2016).

Moreira et al. (2001) studying sheep Santa Ines submitted to scrotal insulation found that changes in the scrotum-testicular biometry are significant from eight days after the insulation end and the scrotal circumference measures returned to baseline after 50 days of treatment.

In animals originated from racial crossing, the average values of $\mathrm{L}, \mathrm{W}, \mathrm{SC}$ and $\mathrm{V}$ before treatment was $8.1 \pm 0.4 \mathrm{~cm}$, $6.0 \pm 0.6 \mathrm{~cm}, 31.3 \pm 0.9 \mathrm{~cm}$ and $459.5 \pm 92.1 \mathrm{~cm}^{3}$ respectively.

Although the L, W, SC and V in crossbred animals were higher than in the Santa Ines, both breeds had undergone significant changes due to thermal stress induced by the scrotum-testicular insulation. However, Santa Ines returned to the values previously observed in shorter period than crossbred.

According Sousa et al. (2008) the fat body condition favors the greater thickness of fat in Dorper x Santa Ines crossbred due to ability of Dorper in accumulate subcutaneous tissue. This explains the fact that the crossbred animals have higher scrotum-testicular circumference values than sheep Santa Ines.

Moreira et al. (2001) studied the effect of scrotal insulation in Santa Ines aged 12 months and with weight of
$53 \pm 1.7 \mathrm{~kg}$ in the city of Fortaleza, Ceará, Brazil. The authors made two measurements before induce thermal stress and found an average on scrotal circumference of $26.4 \pm 1.1 \mathrm{~cm}$. These measures are closer to those found in this study to the same breed, which were $29.4 \pm 4.4 \mathrm{~cm}$.

Mancio et al. (2005) evaluated the effects of different food levels on scrotal circumference and puberty in sheep Australian Merino and found that the increase or reduction in testicular weight was directly related to body weight. For the authors, reproductive variables were related to nutritional and developmental variables. The animals of this study were submitted to the same nutritional food supply, thus, there was no influence of nutritional factors in testicular measurements. This fact may be observed regardless the region in which animals are bred.

Bittencourt et al. (2003) evaluated sheep Santa Ines in agricultural exhibitions and described that scrotal circumference is an important parameter in the evaluation of breeding animals because it is positively correlated with characteristics of fertility, thus promoting the selection of animals with better reproductive potential and high gain of weight.

\section{CONCLUSION}

We conclude, based on the proposed methodology that sheep Santa Ines have greater resistance to thermal stress compared with crossbred sheep (Santa Ines x Dorper).

\section{REFERENCES}

Assis R.M., Perez J.R.O., Barreto Filho J.B., De Paula O.J., Almeida T.R.V., Macedo Junior G.L. \& França P.M. 2008. Evolução do peso testicular de cordeiros da raça Santa Inês alimentados com diferentes níveis de energia. Arq. Bras. Med. Vet. Zootec. 60(5):1219-1226.

Barros N.N., Vasconcelos V.R., Wander A.E. \& Araújo M.R.A. 2005. Eficiência bioeconômica de cordeiros $\mathrm{F}_{1}$ Dorper x Santa Inês para produção de carne. Pesq. Agropec. Bras. 40(8):825-831.

Bittencourt R.F., Ribeiro Filho A. de L., Almeida A.K., Chalhoub M., Alves S.G.G., Portela A.P.M., Guerra R.D., Tinoco A.A.C., Quintela A.T. \& Vale Fi- 
lho V.R. 2003. Avaliação de carneiros da raça Santa Inês baseando-se na circunferência escrotal. Revta Bras. Reprod. Anim. 27(2):195-197.

Boligon A.A., Rorato P.R.N. \& Albuquerque L.G. 2007. Correlações genéticas entre medidas de perímetro escrotal e características produtivas e reprodutivas de fêmeas da raça nelore. Revta Bras. Zootec. 36(3):565-571.

Campos A.C.N., Nunes J.F., Silva Filho A.H.S. \& Monteiro A.W.U. 2003. Parâmetros biométricos do trato genital masculino de caprinos sem raça definida (SRD) criados no semi-árido nordestino durante o período seco e chuvoso. Braz. J. Vet. Res. Anim. Sci. 40(3):185-189.

Dias L.T., El Faro L. \& Albuquerque L.G. 2003. Estimativas de herdabilidade para perímetro escrotal de animais da raça Nelore. Revta Bras. Zootec. 32(6):1878-1882.

Fields M.J., Burns W.C. \& Warnick A.C. 1979. Age, season and breed effects on testicular volume and semen traits in young beef bulls. J. Anim. Sci. 48(6):1299-1304.

Madruga M.S., Araújo W.O., Sousa W.H., Cézar M.F., Galvão M.S. \& Cunha M.G.G. 2006. Efeito do genótipo e do sexo sobre a composição química e o perfil de ácidos graxos da carne de cordeiro. Reva Bras. Zootec. 35(4):1838-1844.

Mancio A.B., Santiago L.L., Tonissi R.H., Goes B., Martins L.F. \& Cecon P.R. 2005. Perímetro escrotal e idade à puberdade em ovinos Merino Australiano submetidos a diferentes regimes alimentares. Acta Scient. Anim. Sci. 27(4):449-457.

Moreira E.P., Moura A.A.A. \& Araújo A.A. 2001. Efeitos da insulação escrotal sobre a biometria testicular e parâmetros seminais em carneiros da raça Santa Inês criados no Estado do Ceará. Revta Bras. Zootec. $30(6): 1704-1711$.

Notter D.R. 2000. Development of sheep composite breeds for lamb pro-

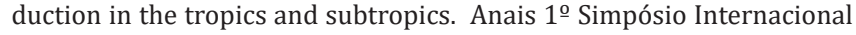
sobre Caprinos e Ovinos de Corte, João Pessoa, Paraíba. Emepa, Brasil, p.141-150.

Nunes J.F., Ciríaco A.L.T. \& Suassuna U. 1997. Produção e Reprodução de Ovinos e Caprinos. $2^{a}$ ed. Ed. Gráfica, Fortaleza, Ceará.

Oliveira A.A.P. \& Lima V.P.M.S. 1994. Aspectos econômicos da caprino-ovinocultura tropical brasileira. Semana da Caprinocultura e da Ovinocultura Tropical Brasileira. Embrapa-CNPC, Sobral, Ceará,

Oliveira D.S., Rogério M.C.P., Batista A.S.M., Alves A.A., Albuquerque F.H.M.A.R., Pompeu R.C.F.F., Guimarães V.P. \& Duarte T.F. 2014. Desem- penho e características de carcaça de cordeiros SPRD cruzados com as raças Santa Inês e Somalis Brasileira terminados em confinamento. Revta Bras. Saúde Prod. Anim. 15(4):937-946.

Santos M.J.C. \& Santos F.R. 2011. Levantamento florístico e fitossociológico em sistema agrossilvipastoril como fonte de alimento para a ovinocultura no semi-árido sergipano. Agropec. Cient. Semi-árido 6(2):15-20.

Santos R.A., Vargas Junior F.M., Seno L.O., Orrico A.C.A., Bottini Filho F.D.E., Senegalhe F.B.D., Cansian K. \& Longo M.L. 2016. Biometria testicular de ovinos Pantaneiros alimentados com níveis crescentes de glicerina bruta na dieta. Revta Bras. Saúde Prod. Anim. 17(2):311-321.

Silva Sobrinho A.G. 2001. Criação de Ovinos. 2ª ed. Funep, Jaboticabal. $302 p$.

Silva A.M., Alencar M.M., Freitas A.R., Barbosa R.T., Barbosa P.F., Oliveira M.C.S., Correia L.A., Novaes A.P. \& Tullio R.R. 2000 Herdabilidade e correlações genéticas para peso e perímetro escrotal de machos e características reprodutivas e de crescimento de fêmeas, na raça Canchim. Revta Bras. Zootec. 29(6):2223-2230.

Sousa W.H., Cartaxo F.Q., Cezar M.F., Gonzaga Neto S., Gomes M.G. \& Santos N.M. 2008. Desempenho e características de carcaça de cordeiros terminados em confinamento com diferentes condições corporais. Revta Bras. Saúde Prod. Anim. 9(4):795-803.

Souza W.H. \& Leite P.R.M. 2000. Ovinos de corte: a raça Dorper. Emepa-PB, João Pessoa. 75p.

Souza J.A.T., Campelo J.E.G., Macedo N.A., Leal T.M., Sousa Júnior A., Medeiros R.M. \& Chaves R.M. 2007. Biometria testicular, características seminais, libido e concentração de testosterona em ovinos da raça Santa Inês, criados a campo, na microrregião de Campo Maior, Piauí. Ciênc. Vet. Trópicos 10(1):21-28.

Teodoro S.M., Pereira A.M.F., Gusmão Filho J.D. \& Da Silva J.N. 2013. Influence of availability of shade on testicular characteristics of Santa Inês rams. Acta Scient. 35(4):441-446.

Unanian M.M., Silva A.E.D.F., Pimentel C.M.M. \& Cardoso E.P. 2000. Características Biométricas Testiculares para Avaliação de Touros Zebuínos da Raça Nelore. Revta Bras. Zootec. 29(1):136-144.

Yokoo M.J.I., Albuquerque L.G., Lobo R.B., Sainz R.D., Carneiro Junior J.M., Bezerra L.A.F. \& Araújo F.R.C. 2007. Estimativas de parâmetros genéticos para altura do posterior, peso e circunferência escrotal em bovinos da raça Nelore. Revta Bras. Zootec. 36(6):1761-1768. 